\title{
Differential influence of four invasive plant species on soil physicochemical properties in a pot experiment
}

\author{
Anna M. Stefanowicz ${ }^{1}$ - Marta L. Majewska ${ }^{2} \cdot$ Malgorzata Stanek $^{1} \cdot$ Marcin Nobis $^{2}$. \\ Szymon Zubek ${ }^{2}$
}

Received: 27 July 2017 / Accepted: 8 November 2017 / Published online: 16 November 2017

(C) The Author(s) 2017. This article is an open access publication

\begin{abstract}
Purpose This study compared the effects of four invasive plants, namely Impatiens glandulifera, Reynoutria japonica, Rudbeckia laciniata, and Solidago gigantea, as well as two native species-Artemisia vulgaris, Phalaris arundinacea, and their mixture on soil physicochemical properties in a pot experiment.

Materials and methods Plants were planted in pots in two loamy sand soils. The soils were collected from fallows located outside (fallow soil) and within river valley (valley soil) under native plant communities. Aboveground plant biomass, cover, and soil physicochemical properties such as nutrient concentrations, $\mathrm{pH}$, and water holding capacity (WHC) were measured after two growing seasons. Discriminant analysis (DA) was used to identify soil variables responsible for the discrimination between plant treatments. Identified variables were further compared between treatments using one-way ANOVA followed by Tukey's HSD test.

Results and discussion Plant biomass, cover, and soil parameters depended on species and soil type. DA effectively separated soils under different plant species. DA on fallow soil data separated $R$. laciniata from all other treatments,
\end{abstract}

Responsible editor: Zucong Cai

Electronic supplementary material The online version of this article (https://doi.org/10.1007/s11368-017-1873-3) contains supplementary material, which is available to authorized users.

Anna M. Stefanowicz

a.stefanowicz@botany.pl

1 W. Szafer Institute of Botany, Polish Academy of Sciences, Lubicz 46, 31-512 Kraków, Poland

2 Institute of Botany, Faculty of Biology and Earth Sciences, Jagiellonian University, Kopernika 27, 31-501 Kraków, Poland especially I. glandulifera, native species and bare soil, along axis 1 (related mainly to exchangeable $\mathrm{K}, \mathrm{N}-\mathrm{NH}_{4}$, total $\mathrm{P}, \mathrm{N}$ $\mathrm{NO}_{3}$, and $\mathrm{WHC}$ ). Large differences were found between R. laciniata and $S$. gigantea as indicated by axis $2\left(\mathrm{~S}_{-} \mathrm{SO}_{4}\right.$, exchangeable $\mathrm{Mg}$, total $\mathrm{P}$, exchangeable $\mathrm{Ca}$, and total $\mathrm{Mg}$ ). DA on valley soil data separated $R$. japonica from all other treatments, particularly $S$. gigantea, $R$. laciniata, and native mixture, along axis $1\left(\mathrm{~N}-\mathrm{NO}_{3}\right.$, total $\mathrm{N}, \mathrm{S}-\mathrm{SO}_{4}$, total $\left.\mathrm{P}, \mathrm{pH}\right)$. Along axis $2\left(\mathrm{~N}-\mathrm{NO}_{3}, \mathrm{~N}-\mathrm{NH}_{4}\right.$, Olsen $\mathrm{P}$, exchangeable $\mathrm{K}$, WHC), large differences were observed between I. glandulifera and all other invaders.

Conclusions Plant influence on soil differed both among invasive species and between invasive and native species. Impatiens glandulifera had a relatively weak effect and its soil was similar to both native and bare soils. Multidirectional effects of different invaders resulted in a considerable divergence in soil characteristics. Invasion-driven changes in the soil environment may trigger feedbacks that stabilize or accelerate invasion and hinder re-colonization by native vegetation, which has implications for the restoration of invaded habitats.

Keywords Impatiens glandulifera · Plant invasion · Reynoutria japonica $\cdot$ Rudbeckia laciniata $\cdot$ Soil nutrient concentrations $\cdot$ Solidago gigantea

\section{Introduction}

Biological invasions are an important human-induced problem at a global scale along with an increase in atmospheric $\mathrm{CO}_{2}$, pollution, and land-use change. Invaders can reduce biological diversity and promote extinctions, act as a vector of diseases, and generate economic losses. The rate of invasion is expected to increase in coming decades, for example, due to the expansion of global trade (Liao et al. 2008). Invasive 
plants change the abundance, diversity, and structure of plant and animal communities (Hejda et al. 2009; Lenda et al. 2013), and often considerably modify physicochemical and biological properties of the soil environment, thereby potentially affecting key ecosystem processes (Vilà et al. 2011; Castro-Díez et al. 2014; Majewska et al. 2015; Stefanowicz et al. 2016; Zubek et al. 2016; Broadbent et al. 2017; CastroDíez and Alonso 2017; Lavoie 2017; Rodríguez-Caballero et al. 2017).

Studies based on meta-analysis indicated that plant invasions generally increase nutrient $(C, N, P)$ pools and also enhance the rate of soil processes such as litter decomposition and mineralization, possibly accelerating nutrient cycling (Liao et al. 2008; Vilà et al. 2011; Castro-Díez et al. 2014). This is because invasive species have significantly higher, in comparison to non-invasive ones, values of performancerelated traits such as physiology, leaf-area allocation, shoot allocation, growth rate, size and fitness, which are driving factors in regulating $\mathrm{C}$ and $\mathrm{N}$ cycles (Liao et al. 2008; Van Kleunen et al. 2010). However, there are also works indicating that the effects of invasion on soil quality and processes are not consistent and depend on invasive plant species, recipient soil, length of invasion history, season, precipitation, and the interactions of these factors (Dassonville et al. 2008; Liao et al. 2008; Tharayil et al. 2013; Stefanowicz et al. 2016). Changes in the soil properties brought about by plant invasion are problematic as they may lead to positive feedbacks that stabilize or accelerate invasion. The changes may persist after the removal of an invasive plant and limit recolonization by native plant communities. This phenomenon, known as invasive plant legacy, has implications for restoration of invaded sites (Corbin and D'Antonio 2012; Broadbent et al. 2017).

Impatiens glandulifera, Reynoutria japonica, Rudbeckia laciniata, and Solidago gigantea are among the most frequent and aggressive invasive alien plants in natural, extensively managed, and man-made habitats in central Europe (Tokarska-Guzik et al. 2010; Zelnik 2012). All these species are considered transformers that change "the character, condition, form or nature of ecosystems over a substantial area" due to, for example, excessive or limited use of resources, promotion of erosion or stabilization of soil, or accumulation of litter (Richardson et al. 2000; Tokarska-Guzik et al. 2010). However, some data indicated that the influence of invasion on ecosystems may considerably vary among transformer invasive species. For example, I. glandulifera invasion had a marginal effect on vegetation and soil properties, which makes this species different from other major invasive aliens in central Europe such as Reynoutria spp. or Heracleum mantegazzianum (Hejda and Pyšek 2006; Hejda et al. 2009; Čuda et al. 2017). As plants affect soil mainly through the root system (root exudates, nutrient uptake) and litter deposition, the distinct effect of $I$. glandulifera on soil in relation to other invaders may result from its annual life form, shallower rooting depth, and/or higher tissue quality (Beerling and Perrins 1993; Weston et al. 2005; Dassonville et al. 2008; Scharfy et al. 2011). Similarly, species belonging to various functional groups may affect ecosystems differently due to the fact that they differ from each other in many traits related to, for example, biomass quantity and quality (Scharfy et al. 2011).

Most previous studies on the effects of I. glandulifera, $R$. japonica, and/or S. gigantea included only a single invasive species, a single or few study sites and the results obtained were inconsistent, indicating increases, decreases, or no change in soil properties under a particular invader in comparison to uninvaded soil (Chapuis-Lardy et al. 2006; Vanderhoeven et al. 2006; Dassonville et al. 2007; Scharfy et al. 2009; Aguilera et al. 2010; Tharayil et al. 2013; Mincheva et al. 2014; Quist et al. 2014; Ruckli et al. 2014b; Stefanowicz et al. 2017). To our knowledge, information on the effect of $R$. laciniata on soil physicochemical properties is scarce (Stefanowicz et al. 2017). Moreover, overwhelming majority of studies was conducted in the field, making pairwise comparisons of soils under patches of invasive species with those under neighboring native vegetation (ChapuisLardy et al. 2006; Vanderhoeven et al. 2006; Dassonville et al. 2007; Aguilera et al. 2010; Tharayil et al. 2013; Mincheva et al. 2014; Quist et al. 2014; Ruckli et al. 2014b; Stefanowicz et al. 2017). Although such space-for-time substitution approach provides a valuable wealth of information, it suffers from drawbacks such as the possibility that potential differences between invaded and native stands existed prior to the invasion. Taking into account the limitations of field studies, it is advantageous to complement research with experiments that include plant cultivation in standardized soil. In such experiments, soil parameters can be directly compared not only between invasive and native species, but also between different invaders. Such a comparison can be problematic in the field as near-monoculture patches of various invaders rarely grow close to each other. Short-term pot experiments based on plant cultivation do not ideally mimic the field situation due to their short duration, lower plant biomass and litter deposition, and/or restricted rooting depth. However, they can simulate a primary stage of an invasion - the encroachment of alien plants onto disturbed (plant biomass removal, sieving, mixing) soil, temporarily devoid of vegetation.

To date, only few experimental studies have tested the impact of I. glandulifera, R. japonica, R. laciniata, or S. gigantea on soil (Scharfy et al. 2010, 2011; Bardon et al. 2014, 2016). Scharfy et al. (2010) performed a mesocosm experiment simulating the invasion of a single species-S. gigantea into three wetland plant communities and found no invasion effect on $\mathrm{N}$ and $\mathrm{P}$ availability in soil. In another experiment, six invasive forbs, including I. glandulifera, R. japonica, and S. gigantea, were compared with the groups of native forbs and 
graminoids in respect of their effects on soil properties, suggesting no significant differences in soluble phenolics, nitrate, ammonium, or phosphate concentrations between the species groups (Scharfy et al. 2011). Other experiments proved that extracts from the roots and rhizomes of $R$. japonica inhibit denitrification (Bardon et al. 2014, 2016). Comparison of the effects of the above-mentioned invaders on the properties of standardized soil would contribute to our knowledge on the invasion impact on ecosystems.

The aim of this study was to compare the effect of the growth of four plant species that are invasive in Europe, namely Impatiens glandulifera, Reynoutria japonica, Rudbeckia laciniata, and Solidago gigantea, as well as two native species-Artemisia vulgaris, Phalaris arundinacea, and their mixture on physicochemical properties such as total and available nutrient concentrations, water holding capacity, and $\mathrm{pH}$ of two soils in a pot experiment. We hypothesized that soil properties would differ both among invaders as well as between invasive and native species. The weakest effect on soil was expected in the case of I. glandulifera. Moreover, the influence of the two native species-A. vulgaris and $P$. arundinacea - on soil would differ from each other as these species belong to distinct functional groups - graminoids and forbs. Finally, plant effect on soil would depend on soil type.

\section{Materials and methods}

\subsection{Plant species}

Four species that are successful invaders in Europe were used in the experiment, namely Impatiens glandulifera Royle [= Impatiens roylei Walpers] (Balsaminaceae), Reynoutria japonica Houtt. [= Fallopia japonica (Houtt.) Ronse Decr., = Polygonum cuspidatum Sieb. \& Zucc.] (Polygonaceae), Rudbeckia laciniata L. (Asteraceae), and Solidago gigantea Aiton [= S. serotina Aiton] (Asteraceae). Impatiens glandulifera is widespread in many parts of Europe and North America. It was first introduced to Europe from the Himalayas in the first half of the nineteenth century (1839) and used as an ornamental and nectar-producing plant. It is the tallest annual species in Europe, reaching up to $2.5 \mathrm{~m}$ (Beerling and Perrins 1993; Pyšek and Prach 1995). Reynoutria japonica is a perennial rhizomatous forb native to Japan, Korea, Taiwan, and northern China, being a pioneer species on volcanic slopes. It was introduced in Europe in 1825 and in North America about 1870 for ornamental purpose (Barney 2006; Barney et al. 2006). Reynoutria japonica produces huge amounts of biomass; its bamboo-like stems can be up to $5 \mathrm{~m}$ high, rhizomes can extend more than $2 \mathrm{~m}$ in depth, 15-20 m in length, and even burrow through asphalt (Barney 2006; Weston et al. 2005).
Rudbeckia laciniata and S. gigantea are both tall (up to $3 \mathrm{~m}$ ) rhizomatous perennial forbs native to North America that were introduced in Europe as ornamentals at the beginning of the 17th and in the middle of eighteenth century (1758), respectively. They are also problematic invasive species in Asia (Weber 1998; Akasaka et al. 2015; CABI 2017). Impatiens glandulifera, $R$. japonica, $R$. laciniata, and $S$. gigantea invade a range of habitats such as riparian zones around standing waters or streams, floodplain woods, forest clearings, swamps, wastelands, grasslands, cultivated field margins, fallows, roadsides, and/or areas along railroad tracks (Zelnik 2012).

Two common rhizomatous perennials native in Europe, belonging to different families and functional groups - the forb Artemisia vulgaris L. (Asteraceae) and the grass Phalaris arundinacea L. (Poaceae) were also selected for the experiment. Both plants are tall and reach $0.5-2.5 \mathrm{~m}$ in height. Artemisia vulgaris and P. arundinacea are considered invaders in North America, infesting roadsides, waste areas, agronomic settings, and/or wetlands (Weston et al. 2005; Jacinthe et al. 2010).

\subsection{Experimental setup and sampling}

Soils for the experiment were collected in April 2014 from fallows located within river valley (the Skawa river in Zator, $49^{\circ} 59^{\prime} 59^{\prime \prime} \mathrm{N}, 19^{\circ} 26^{\prime} 40.5^{\prime \prime}$ E, $265 \mathrm{~m}$ a.s.l.; hereafter referred to as valley soil) and outside valley (Kraków, 49 $59^{\prime} 49.5^{\prime \prime} \mathrm{N}, 19^{\circ}$ $52^{\prime} 13.6^{\prime \prime}$ E, $260 \mathrm{~m}$ a.s.1.; hereafter referred to as fallow soil) in southern Poland under native plant communities (Artemisietea vulgaris). This area lies in the transitional climate zone between a temperate oceanic climate in the west and a temperate continental climate in the east. Mean annual temperature fluctuates between 7 and $9{ }^{\circ} \mathrm{C}$ and precipitation between 700 and $900 \mathrm{~mm}$. The vegetation season (days with an average temperature $>5^{\circ} \mathrm{C}$ ) spans a period between 210 and 230 days. At each site, soil was taken from one plot (approx. $4 \mathrm{~m}^{2}$ ) to a depth of approx. $30 \mathrm{~cm}$. The following plant species were recorded at the plots: Achillea millefolium, Equisetum arvense, Lysimachia vulgaris, P. arundinacea, Poa pratensis, Rubus caesius, Tanacetum vulgare (Zator) and Calamagrostis epigejos, Cirsium arvense, Hypericum perforatum, Lathyrus pratensis, Lysimachia vulgaris, Lythrum salicaria, Phragmites communis, Rubus caesius, Sanguisorba officinalis, Selinum carvifolia, Tanacetum vulgare (Kraków). Collected soils were homogenized by sieving (15-mm mesh) and mixing, and then placed in pots (10 L volume, $25 \mathrm{~cm}$ wide $\times 30 \mathrm{~cm}$ high). The seeds of five studied species and the rhizomes of $R$. japonica were gathered in October 2013 and in April 2014, respectively, from the same area as soils. The seeds were stored at $4{ }^{\circ} \mathrm{C}$. The rhizomes were used to set up the experiment directly after their collection. All species with the exception of $R$. japonica, the reproduction of which in Europe is mainly vegetative (Dassonville et al. 2007), were sowed (ca. 30 seeds per pot) 
and rhizomes of $R$. japonica (one rhizome per pot) were planted in April 2014 directly in the experimental pots. The seeds were homogenously scattered on the soil surface and coated with $0.5 \mathrm{~cm}$ of soil layer. In the case of annual I. glandulifera, 30 seeds per pot were also sowed in the second year. The following plant treatments were established in each soil in six replicates (1) bare soil, (2) native A. vulgaris, (3) native $P$. arundinacea, (4) native $A$. vulgaris $+P$. arundinacea, (5) invasive I. glandulifera, (6) invasive $R$. japonica, (7) invasive $R$. laciniata, and (8) invasive $S$. gigantea, giving a total of 96 pots. The pots were arranged in a random manner and kept under natural atmospheric and light conditions in the Botanical Garden of the Jagiellonian University ( $50^{\circ} 3^{\prime} 57.8$ $\mathrm{N}, 19^{\circ} 57^{\prime} 19.0 \mathrm{E}$ ) for two growing seasons (since 12th April 2014 to 25th August 2015). The plants were watered in spring and summer with the same volume of tap water (1 L per pot) when precipitation was insufficient. Mean values of selected properties of tap water were as follows: $\mathrm{pH}-7.7$, nitrites$<0.02 \mathrm{mg} / \mathrm{L}$, nitrates-10.5 mg/L, Ca-73.4 mg/L, and $\mathrm{Mg}-8.2 \mathrm{mg} / \mathrm{L}$ (MPWiK 2015, 2016). All emerging weeds were removed by hand. In winter, the pots were wrapped with a bubble wrap to prevent plants from freezing.

At the end of the experiment, plant cover in each pot was recorded and then aboveground plant biomass was harvested. A whole volume of soil was pulled out from each pot and an outer soil layer (up to $3 \mathrm{~cm}$ ) was discarded. Then the soil from each pot was thoroughly mixed and subsamples for physicochemical analyses were collected. Additionally, six replicates of each soil used to establish the experiment (initial soil) were analyzed along with pot soils, giving a total of 108 samples.

\subsection{Laboratory work}

Plant biomass was dried at $80{ }^{\circ} \mathrm{C}$ for $48 \mathrm{~h}$ and weighted. Twenty physicochemical parameters were measured in all soil samples. These were $\mathrm{pH}$, maximum water holding capacity (WHC), the contents of organic matter, organic $\mathrm{C}$, total $\mathrm{C}, \mathrm{Ca}$, $\mathrm{Fe}, \mathrm{K}, \mathrm{Mg}, \mathrm{N}, \mathrm{Na}, \mathrm{P}, \mathrm{S}$, exchangeable $\mathrm{Ca}, \mathrm{K}, \mathrm{Mg}$, Olsen P, N$\mathrm{NH}_{4}, \mathrm{~N}-\mathrm{NO}_{3}$, and $\mathrm{S}-\mathrm{SO}_{4}$. Texture of two initial soils that had been used to establish the experiment was also determined. Soil samples were sieved (2-mm mesh), dried at room temperature or at $105^{\circ} \mathrm{C}$, depending on analysis. Soil texture was determined through a combination of sieving and sedimentation (ISO 11277 1998) and WHC according to Öhlinger (1996) with modifications. Soil pH was measured in 1:5 $(w: v)$ water suspensions with a Hach HQ40D meter. Organic matter, total, and organic $\mathrm{C}$ were determined with a Leco $\mathrm{RC}$ 612, and total S with a Leco SC-144 DR dry combustion analyzer in ground soil. Total $\mathrm{N}$ was measured using the Kjeldahl method; ground soil was digested in $\mathrm{H}_{2} \mathrm{SO}_{4}$ with Kjeltabs $\left(\mathrm{K}_{2} \mathrm{SO}_{4}+\mathrm{CuSO}_{4} \cdot 5 \mathrm{H}_{2} \mathrm{O}\right.$; Foss Tecator Digestor Auto) followed by distillation on a Foss Tecator Kjeltec 2300 Analyzer Unit. The available P (Olsen P) was measured with an ion chromatograph (Dionex ICS-1100) following soil extraction with $0.5 \mathrm{M} \mathrm{NaHCO}_{3}(1: 10, w: v)$. To analyze N$\mathrm{NH}_{4}, \mathrm{~N}-\mathrm{NO}_{3}$, and $\mathrm{S}-\mathrm{SO}_{4}$, soil was shaken in water for $1 \mathrm{~h}$ $(1: 10, w: v)$, and $\mathrm{N}-\mathrm{NO}_{3}$ and $\mathrm{S}-\mathrm{SO}_{4}$ in the extracts were determined with Dionex ICS-1100, while $\mathrm{N}_{-} \mathrm{NH}_{4}$ with Dionex DX100. Total $\mathrm{Ca}, \mathrm{Fe}, \mathrm{K}, \mathrm{Mg}, \mathrm{Na}, \mathrm{P}$, and exchangeable $\mathrm{Ca}, \mathrm{K}$, and $\mathrm{Mg}$ were extracted by digestion of ground soil in hot concentrated $\mathrm{HClO}_{4}$ (Foss Tecator Digestor Auto) or shaking soil in $0.1 \mathrm{M} \mathrm{BaCl}_{2}$ (ISO 11260 1996), respectively. Extracted elements were analyzed with flame atomic absorption spectrometry (Varian AA280FS), with the exception of total P, which was measured colorimetrically (Hach-Lange DR 3800). Two certified reference materials, namely CRM048-050 (RTC; total) and ISE-912 (WEPAL; exchangeable) were used to estimate the quality of metal analyses in soil. The recovery values for total metals ranged from $95(\mathrm{Na})$ to $99 \%(\mathrm{Fe}, \mathrm{K})$ and for exchangeable metals from $87(\mathrm{Ca})$ to $99 \%(\mathrm{~K})$.

\subsection{Statistical analysis}

Prior to statistical analysis, all variables were transformed with a logarithmic or exponential function to obtain a normal or at least symmetrical distribution. The variables were then standardized to get values ranging from 0 to 1 . Two-way ANOVA was performed to test the effect of plant species, soil type, and their interactions on plant biomass and cover. If plant species $\times$ soil type interactions were significant $(p<0.05)$ or marginally significant $(p<0.1)$, plant species effects on plant biomass and cover were assessed separately for each soil type using one-way ANOVA followed by post-hoc Tukey's HSD test. Reynoutria japonica was excluded from statistical analyses involving plant biomass and cover as it was planted from rhizomes, and thus, is hardly comparable with other species.

Cluster analysis (single linkage, Euclidean distance) on physicochemical variables was used to explore the grouping of soil samples. Initial fallow and valley soils were compared in terms of physicochemical properties using Student's $t$ test. Discriminant analysis (DA) was performed separately on fallow and valley data to identify the combinations of physicochemical variables discriminating soils under different plant species the most effectively. Variables with the highest contribution to discriminating axes were identified on the basis of their loading values. These variables were further compared between plant species using one-way ANOVA followed by post-hoc Tukey's HSD test. Pearson's correlations between plant biomass and soil properties were assessed. Statistical analysis employed STATISTICA 12 and PAST 3.14 (Hammer et al. 2001).

\section{Results}

Aboveground plant biomass in experimental pots was affected by species $\left(\mathrm{F}_{5,60}=16.1, p<0.001\right)$, soil type $\left(\mathrm{F}_{1,60}=37.9\right.$, 
$\mathrm{p}<0.001)$, and species $\times$ soil type interaction $\left(\mathrm{F}_{5,60}=2.75\right.$, $p=0.027$ ). Plant biomass of most species was higher on fallow than on valley soil (Table 1). Reynoutria japonica was distinguished by the highest biomass as it was planted from rhizomes. Among species planted from seeds, the lowest biomass was observed in the case of I. glandulifera and the highest in a species mixture (A. vulgaris $+P$. arundinacea) growing in both soil types (Table 1). Plant cover in experimental pots was significantly affected by species $\left(\mathrm{F}_{5,60}=13.5\right.$, $p<0.001)$ and soil type $\left(\mathrm{F}_{1,60}=10.0, p=0.002\right)$. The effect of species $\times$ soil type interaction on plant cover was marginally significant $\left(\mathrm{F}_{5,60}=2.17, p=0.07\right)$. Plant cover was either similar on the two soil types or higher on fallow soil (Table 1). Reynoutria japonica was characterized by the lowest cover. Among species planted from seeds, the lowest cover was observed in I. glandulifera and the highest in R. laciniata in both soils (Table 1).

Both soil types used in the experiment were classified as loamy sand. Fallow and valley soils contained 84 and $87 \%$ sand, 7 and $4 \%$ silt, and $9 \%$ clay, respectively. Despite the similarity in texture, initial fallow and valley soils differed significantly $(p<0.05)$ in terms of nearly all soil physicochemical properties. Initial fallow soil had higher WHC, organic matter and organic $\mathrm{C}$ content, total $\mathrm{C}$ and $\mathrm{N}$, exchangeable $\mathrm{Mg}$ and Olsen $\mathrm{P}$ concentrations, but lower concentrations of total $\mathrm{Ca}, \mathrm{Fe}, \mathrm{K}, \mathrm{Mg}$, and $\mathrm{Na}$, exchangeable $\mathrm{Ca}$ and $\mathrm{K}, \mathrm{N}$ $\mathrm{NH}_{4}$, and $\mathrm{pH}$ than initial valley soil (Tables $\mathrm{S} 1$ and $\mathrm{S} 2$, Electronic Supplementary Material). Cluster analysis also showed that fallow and valley soils grouped into clearly distinguishable clusters (Fig. 1). As very large differences between soil types can affect multivariate analysis and/or hinder the detection of more subtle differences (i.e., those between plant species), DA was performed separately for each soil type.

Discriminant analysis on both fallow and valley soil data showed that plant species treatments were separated effectively. The largest discrimination was observed among invasive species (Figs. 2 and 3). Invasive plants, with the exception of I. glandulifera, also differed considerably from native species (Figs. 2 and 3). The concentrations of N-NO $3, \mathrm{~N}^{-N_{4}}, \mathrm{~S}_{-} \mathrm{SO}_{4}$, exchangeable $\mathrm{K}$, total $\mathrm{P}$, and $\mathrm{WHC}$ were among the most important variables for the discrimination of plant species treatments in both soil types (Table 2). The first two DA axes explained jointly $76.8 \%$ of variance in fallow soil data (Table 2). Exchangeable $\mathrm{K}, \mathrm{N}-\mathrm{NH}_{4}$, total $\mathrm{P}, \mathrm{N}-\mathrm{NO}_{3}$, and WHC had the highest loadings on the first and $\mathrm{S}_{-} \mathrm{SO}_{4}$, exchangeable $\mathrm{Mg}$, total $\mathrm{P}$, exchangeable $\mathrm{Ca}$, and total $\mathrm{Mg}$ on the second axis (Table 2). Rudbeckia laciniata stood away from all other species (Fig. 2). The largest distance along the first axes was found between invasive $R$. laciniata (right side of the diagram) and invasive I. glandulifera, native species, and bare soil (left side) (Fig. 2). Overall, the former had relatively low concentrations of exchangeable $\mathrm{K}$ (Fig. 4a), $\mathrm{N}^{-\mathrm{NH}_{4}}$ 


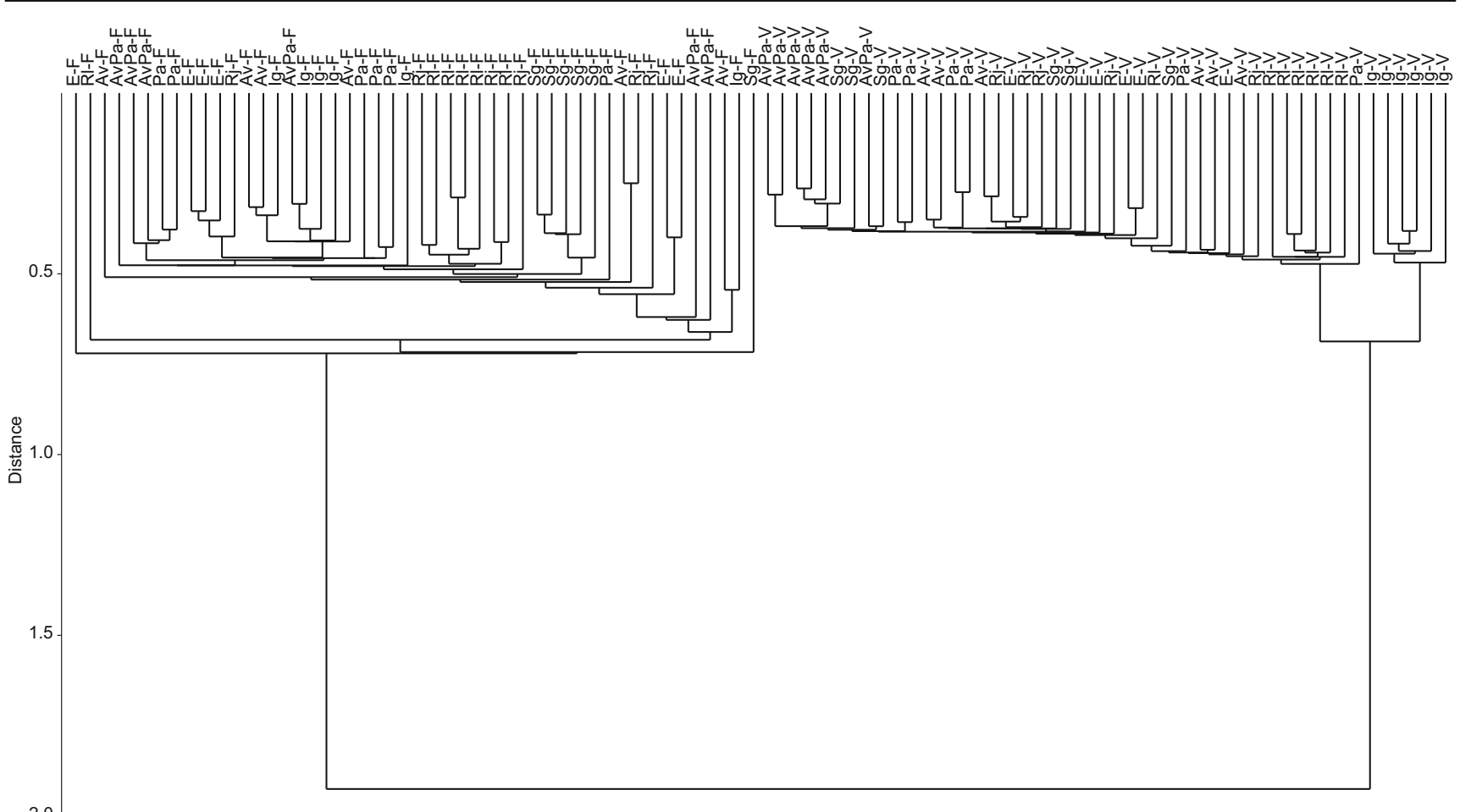

Fig. 1 Results of cluster analysis on soil physicochemical properties. Plant species: E- empty pot (bare soil); Native: $\mathrm{Av}-A$. vulgaris, $\mathrm{Pa}-$ P. arundinacea, AvPa - a mixture of A. vulgaris and P. arundinacea;

(Fig. 4b) and $\mathrm{N}-\mathrm{NO}_{3}$ (Fig. 4c), and high concentration of total $\mathrm{P}$ (Fig. 4d) in comparison to the latter (though there also were some exceptions). All invasive species, with the exception of I. glandulifera, were located on the right side of the diagram
Invasive: $\mathrm{Ig}-I$. glandulifera, $\mathrm{Rj}-R$. japonica, $\mathrm{Rl}-R$. laciniata, $\mathrm{Sg}-$ $S$. gigantea. Soil type: F-fallow, V-valley

(Fig. 2), probably due to very low $\mathrm{N}-\mathrm{NH}_{4}$ concentration in soil (Fig. 4b). According to DA (Table 2, Fig. 2), soil WHC also contributed to the discrimination between species - the lowest values were found under invasive $S$. gigantea and native

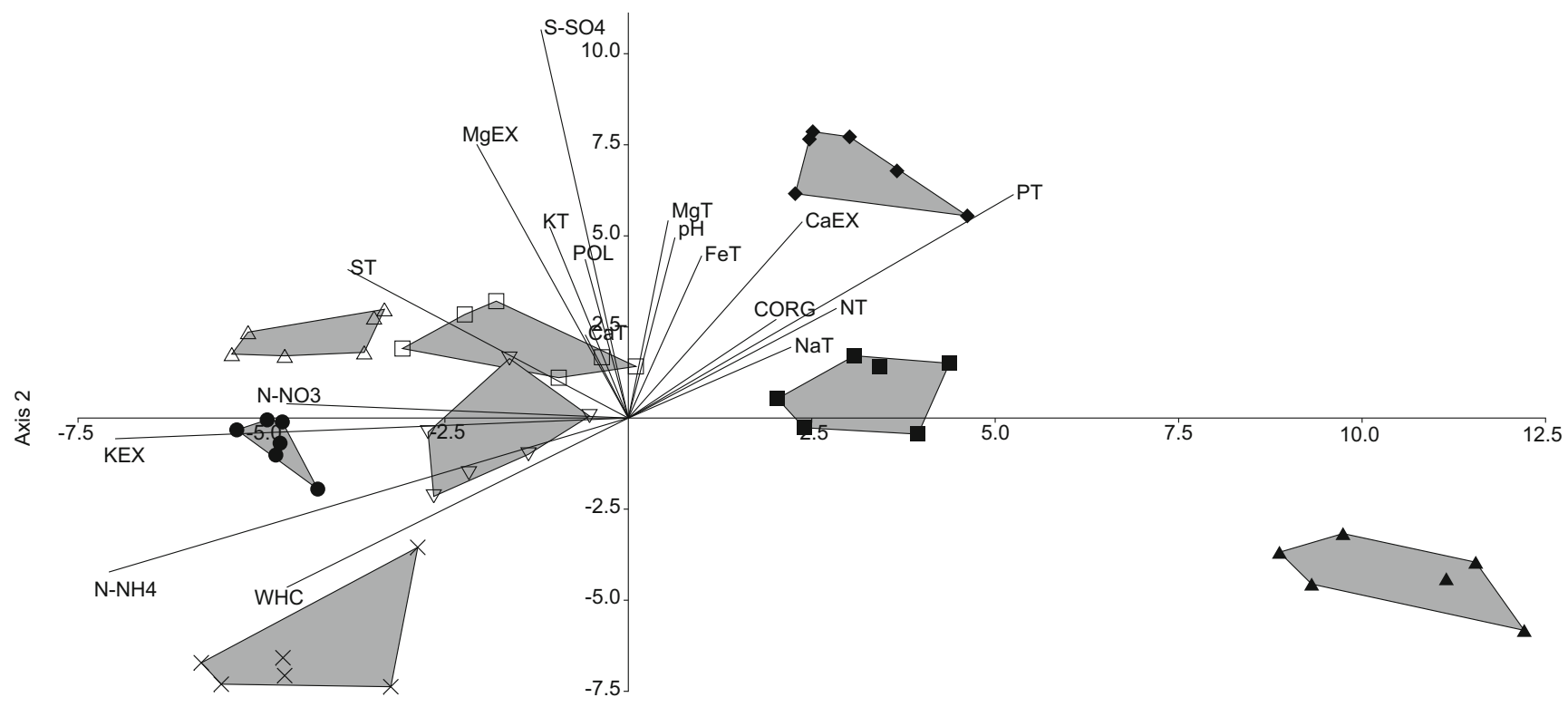

Axis 1

Fig. 2 Two-dimensional plot of the discriminant analysis based on physicochemical properties of fallow soil. Black symbols indicate invasive species (black dots-I. glandulifera, black squares$R$. japonica, black triangles-R. laciniata, black diamonds-
S. gigantea), empty symbols indicate native species (trianglesA. vulgaris, inverted triangles- $P$. arundinacea, and squares - a mixture of A. vulgaris and $P$. arundinacea), and $\times$ indicates bare soil. EXexchangeable, $\mathrm{OL}$ - Olsen, ORG — organic, $\mathrm{T}$ - total 


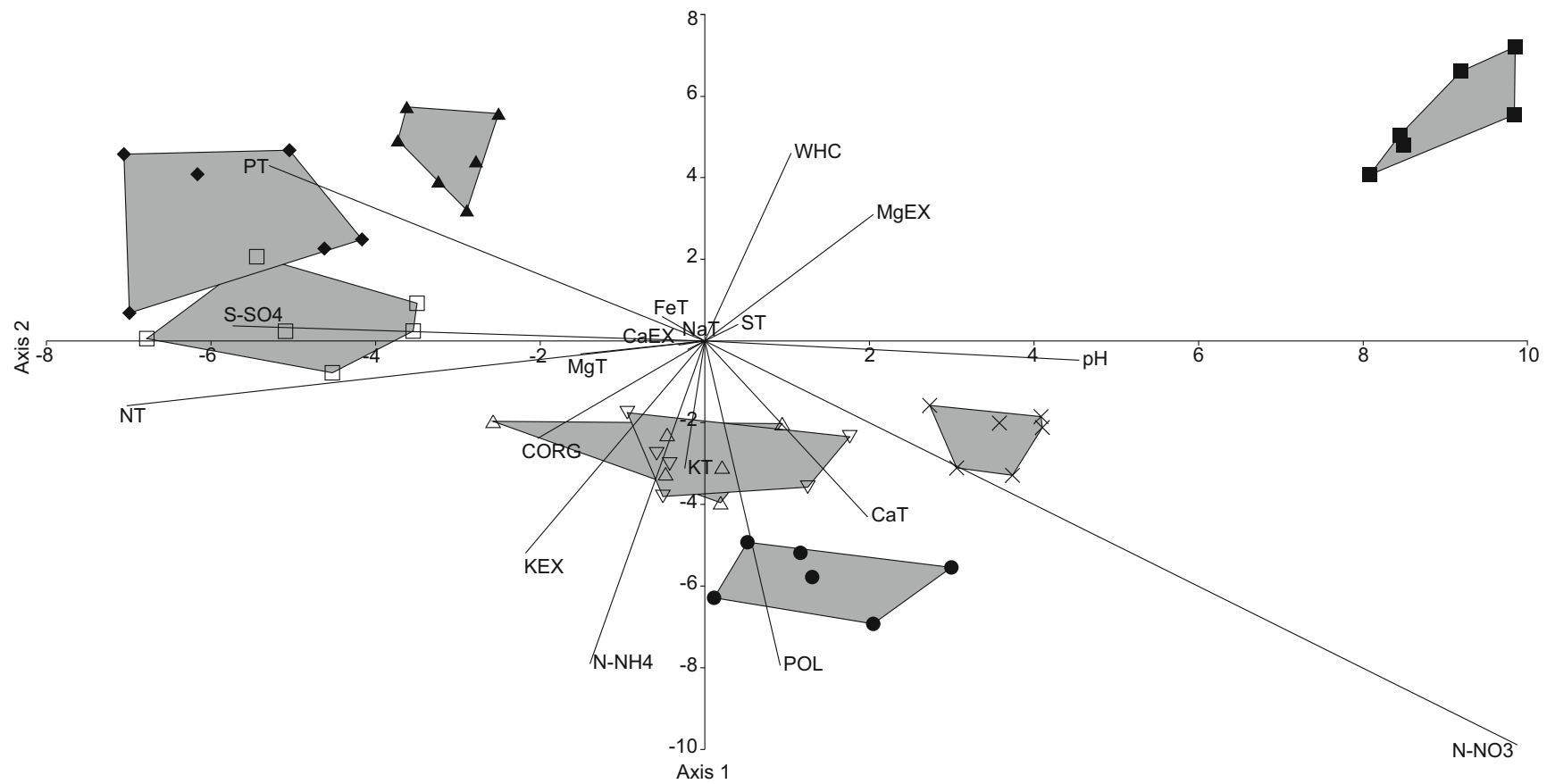

Fig. 3 Two-dimensional plot of the discriminant analysis based on physicochemical properties of valley soil. Black symbols indicate invasive species (black dots-I. glandulifera, black squares$R$. japonica, black triangles-R. laciniata, black diamonds-

species mixture and the highest in bare soil, under native A. vulgaris and invasive I. glandulifera (Fig. 4e). Two invaders, namely $R$. laciniata and $S$. gigantea, differed considerably between each other as indicated by their positions on the diagram - the former was located at the bottom and the latter at its opposite side (Fig. 2). In general, $R$. laciniata had lower concentrations of $\mathrm{S}_{-} \mathrm{SO}_{4}$ (Fig. 4f), exchangeable $\mathrm{Mg}$ (Fig. 4g), and $\mathrm{Ca}$ (Fig. 4h). Total Mg differed significantly $(p<0.05)$ only between bare soil (low concentrations) and native species mixture (high concentrations) (Table S1, Electronic Supplementary Material).

The pattern obtained by DA on valley soil data was somewhat similar to that for fallow soil for two reasonsinvasive I. glandulifera stood closer to bare soil and most native treatments than to other invaders, and another invader (R. japonica in this case) stood out from all other treatments (Fig. 3). The first two DA axes explained jointly $64.9 \%$ of variance in the data (Table 2). The concentrations of $\mathrm{N}^{-\mathrm{NO}_{3}}$ in soil contributed highly to both DA axes, followed by total $\mathrm{N}, \mathrm{S}_{-} \mathrm{SO}_{4}$, total $\mathrm{P}$, and $\mathrm{pH}$ (axis 1 ) and $\mathrm{N}-\mathrm{NH}_{4}$, Olsen $\mathrm{P}$, and exchangeable $\mathrm{K}$ (axis 2) (Table 2). Invasive species were separated along both the first and the second axes (Fig. 3). Rudbeckia laciniata and $S$. gigantea clustered on the left side together with native species mixture, and $R$. japonica on the right side of the diagram. In general, $R$. japonica soil had higher $\mathrm{N}^{-N_{3}}$ (Fig. 5a) and $\mathrm{pH}$ (Fig. 5b), but lower total $\mathrm{N}$ (Fig. 5c), P (Fig. 5d), and $\mathrm{S}^{-S} 4$ (Fig. 5e) concentrations in comparison to $R$. laciniata and/or $S$. gigantea.
S. gigantea), empty symbols indicate native species (trianglesA. vulgaris, inverted triangles - $P$. arundinacea, and squares - a mixture of $A$. vulgaris and $P$. arundinacea) and $\times$ - bare soil. EX — exchangeable, $\mathrm{OL}$-Olsen, ORG-organic, T-total

Impatiens glandulifera lied in the bottom of the diagram, in contrast to three other invaders (Fig. 3). It had strikingly high concentrations of $\mathrm{N}^{-N_{3}}$ (Fig. 5a), N-NH $\mathrm{N}_{4}$ (Fig. 5f), and Olsen P (Fig. 5g) when compared to all other invaders and some native treatments. Soil under R. japonica had the lowest exchangeable K (Fig. 5h) among all species. Soil WHC differed significantly $(p<0.05)$ between native $P$. arundinacea, invasive $I$. glandulifera (low), and $R$. laciniata (high) (Table S2, Electronic Supplementary Material). Mean values and standard deviations of physicochemical properties, including those that contributed less or did not contribute to the discrimination of plant species treatments in DA (Table 2), are presented in Tables S1 and S2 (Electronic Supplementary Material).

Plant aboveground biomass was significantly correlated with some soil parameters, indicating that species influence on soil may depend on its biomass. Positive relationships between plant biomass and parameters of fallow soil were found for total $\mathrm{Fe}(r=0.40, p=0.015), \mathrm{Na}(r=0.42, p=0.010), \mathrm{Mg}$ $(r=0.37, p=0.028), \mathrm{Ca}(r=0.35, p=0.038), \mathrm{P}(r=0.52$, $p=0.0013)$, and negative for WHC $(r=-0.48, p=0.0029)$, exchangeable $\mathrm{K}(r=-0.33, p=0.048), \mathrm{N}^{-\mathrm{NO}_{3}}(r=-0.37$, $p=0.028)$, and $\mathrm{N}^{-\mathrm{NH}_{4}}(p=-0.41, p=0.012)$. Positive relationships between plant biomass and valley soil parameters were found for WHC $(r=0.33, p=0.047)$, total P $(r=0.38$, $p=0.021)$, and negative for exchangeable $\mathrm{K}(r=-0.42$, $p=0.010)$, Olsen $\mathrm{P}(r=-0.60, p<0.001)$, and $\mathrm{N}-\mathrm{NO}_{3}$ $(r=-0.64, p<0.001$; Fig. 6$)$. 
Table 2 Results of discriminant analysis performed separately for fallow and valley soils

\begin{tabular}{|c|c|c|c|c|}
\hline & \multicolumn{2}{|c|}{ Fallow soil } & \multicolumn{2}{|c|}{ Valley soil } \\
\hline & Axis 1 & Axis 2 & Axis 1 & Axis 2 \\
\hline Eigenvalues & 29.4 & 17.8 & 24.1 & 17.5 \\
\hline Variance explained (\%) & 47.9 & 28.9 & 37.6 & 27.3 \\
\hline \multicolumn{5}{|l|}{ Loadings } \\
\hline $\mathrm{pH}$ & 0.003 & 0.021 & 0.022 & -0.002 \\
\hline WHC & -0.020 & -0.020 & 0.005 & 0.023 \\
\hline $\mathrm{C}_{\mathrm{ORG}}$ & 0.009 & 0.011 & -0.010 & -0.012 \\
\hline $\mathrm{Ca}_{\mathrm{T}}$ & -0.002 & 0.010 & 0.010 & -0.021 \\
\hline $\mathrm{Ca}_{\mathrm{EX}}$ & 0.010 & 0.023 & -0.002 & 0.000 \\
\hline $\mathrm{Fe}_{\mathrm{T}}$ & 0.004 & 0.019 & -0.003 & 0.003 \\
\hline $\mathrm{K}_{\mathrm{T}}$ & -0.005 & 0.022 & -0.001 & -0.015 \\
\hline $\mathrm{K}_{\mathrm{EX}}$ & -0.030 & -0.002 & -0.011 & -0.026 \\
\hline $\mathrm{Mg}_{\mathrm{T}}$ & 0.002 & 0.023 & -0.007 & -0.002 \\
\hline $\mathrm{Mg}_{\mathrm{EX}}$ & -0.009 & 0.032 & 0.010 & 0.015 \\
\hline $\mathrm{N}_{\mathrm{T}}$ & 0.012 & 0.013 & -0.035 & -0.008 \\
\hline $\mathrm{N}-\mathrm{NH}_{4}$ & -0.030 & -0.018 & -0.007 & -0.039 \\
\hline $\mathrm{N}-\mathrm{NO}_{3}$ & -0.020 & 0.002 & 0.049 & -0.049 \\
\hline $\mathrm{Na}_{\mathrm{T}}$ & 0.009 & 0.008 & -0.001 & -0.001 \\
\hline $\mathrm{P}_{\mathrm{T}}$ & 0.022 & 0.026 & -0.026 & 0.021 \\
\hline $\mathrm{P}_{\mathrm{OL}}$ & -0.002 & 0.018 & 0.005 & -0.039 \\
\hline $\mathrm{S}_{\mathrm{T}}$ & -0.016 & 0.017 & 0.002 & 0.002 \\
\hline $\mathrm{S}-\mathrm{SO}_{4}$ & -0.005 & 0.045 & -0.028 & 0.002 \\
\hline
\end{tabular}

Initial soil was excluded from analysis

Variables with the highest loadings on each axis are given in italics

EX exchangeable, OL Olsen, ORG organic, T total

\section{Discussion}

Our study compared the effects of the growth of four invasive species-I. glandulifera, R. japonica, R. laciniata, and $S$. gigantea - on the physicochemical properties of two soils in a two-year pot experiment. It showed that these invasive plants significantly influenced most soil properties. The influence differed in terms of magnitude and direction both between invasive and native species and among invasive species. The multidirectional effects of different invaders resulted in a considerable divergence in soil characteristics. Overall, total and available forms of $\mathrm{N}\left(\mathrm{N}-\mathrm{NO}_{3}, \mathrm{~N}-\mathrm{NH}_{4}\right)$ and $\mathrm{P}$ (Olsen), $\mathrm{S}_{-} \mathrm{SO}_{4}$, exchangeable $\mathrm{K}$, and $\mathrm{Mg}$ contributed the most to the discrimination of soils under different plant species.

The influence of invasive I. glandulifera, $R$. japonica, and $S$. gigantea on soil has been estimated earlier in numerous field studies (Chapuis-Lardy et al. 2006; Vanderhoeven et al. 2006; Dassonville et al. 2008; Scharfy et al. 2009; Maurel et al. 2010; Tharayil et al. 2013; Quist et al. 2014; Ruckli et al. 2013, 2014b; Stefanowicz et al. 2017), but experiments
Fig. 4 Physicochemical properties of fallow soil (means and standard errors). Only variables highly contributing to the discrimination of plant species treatments are presented. Means bearing different letters differ significantly $(p<0.05)$ according to Tukey's HSD test. Plant species: E-empty pot (bare soil); Native: Av-A. vulgaris, $\mathrm{Pa}-$ $P$. arundinacea, $\mathrm{AvPa}-\mathrm{a}$ mixture of $A$. vulgaris and $P$. arundinacea; Invasive: $\mathrm{Ig}-I$. glandulifera, $\mathrm{Rj}-R$. japonica, $\mathrm{Rl}-R$. laciniata, $\mathrm{Sg}-$ S. gigantea

concerning this problem are rare (Scharfy et al. 2010, 2011; Bardon et al. 2014, 2016). Previous studies focused mainly on invasion-induced changes in different forms of $\mathrm{N}$ and $\mathrm{P}$ in soil and found that these properties responded variably to the presence of I. glandulifera, R. japonica, or S. gigantea, and so did some exchangeable cations, for example $\mathrm{K}$ and $\mathrm{Mg}$ (ChapuisLardy et al. 2006; Hejda and Pyšek 2006; Vanderhoeven et al. 2006; Dassonville et al. 2007; Scharfy et al. 2009, 2010, 2011; Tharayil et al. 2013; Ruckli et al. 2014b; Stefanowicz et al. 2017). Specifically, our field study indicated that $N$ and $P$ were the only soil physicochemical variables that reacted to invasion; total $\mathrm{P}$ decreased significantly under invasive species$R$. japonica, $R$. laciniata, and $S$. gigantea, and $\mathrm{N}^{-\mathrm{NO}_{3}}$ increased under $R$. japonica in comparison to native vegetation (Stefanowicz et al. 2017). Another study revealed that $S$. gigantea invasion significantly increased available $\mathrm{P}$ and decreased $\mathrm{N}-\mathrm{NO}_{3}$ concentration, but did not induce any changes in many other soil variables, including exchangeable cations, in comparison to native plants (Vanderhoeven et al. 2006). An increase in soil available $P$ was also detected under S. gigantea and I. glandulifera in comparison to uninvaded sites (Chapuis-Lardy et al. 2006; Ruckli et al. 2014b). On the other hand, no differences in soil $\mathrm{C}$ and $\mathrm{N}$ were found between patches of $R$. japonica and adjacent areas (Aguilera et al. 2010). Similarly, soil total phenolics, N, and P did not differ between the groups of invasive forbs, including I. glandulifera, $R$. japonica, and $S$. gigantea, native forbs and native graminoids (Scharfy et al. 2011). Overall, it seems that increases or no changes in soil nutrient concentrations due to the invasion of these species prevail over decreases (Güsewell et al. 2005; Vanderhoeven et al. 2005, 2006; Chapuis-Lardy et al. 2006; Dassonville et al. 2007; Aguilera et al. 2010; Mincheva et al. 2014; Ruckli et al. 2014a; Scharfy et al. 2009, 2010, 2011; Stefanowicz et al. 2017).

Physicochemical soil properties may be affected by plants both directly and indirectly - through modification of the activity, biomass, or microbial community structure, which in turn results in changes in organic matter decomposition and other soil processes, and thus, in concentrations of total and available nutrients in soil. A few experimental and field works have consistently reported the ability of $R$. japonica to modify $\mathrm{N}$ turnover (Hirose and Tateno 1984; Tharayil et al. 2013; Bardon et al. 2014, 2016; Stefanowicz et al. 2016). This species increases, at least seasonally, the concentration of $\mathrm{N}-\mathrm{NO}_{3}$ in soil in comparison to native vegetation, presumably due to 
(a)

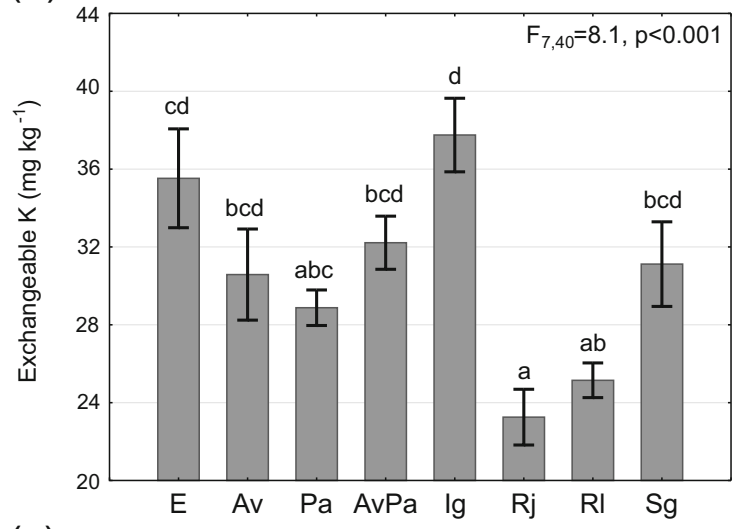

(c)

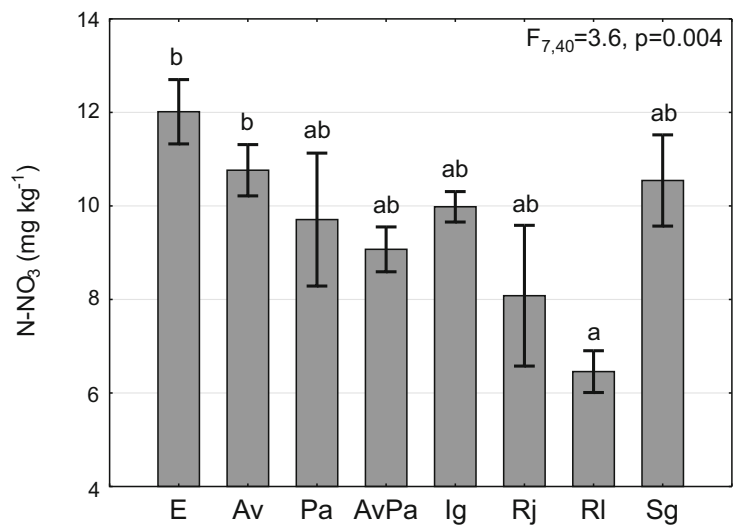

(e)

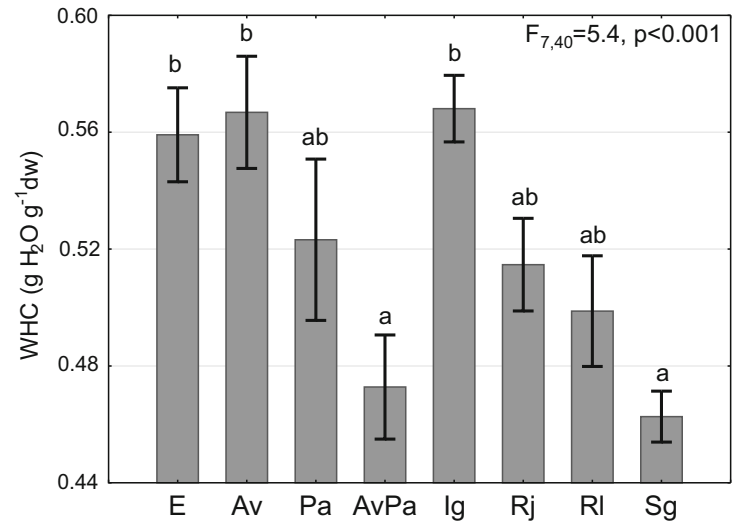

(g)

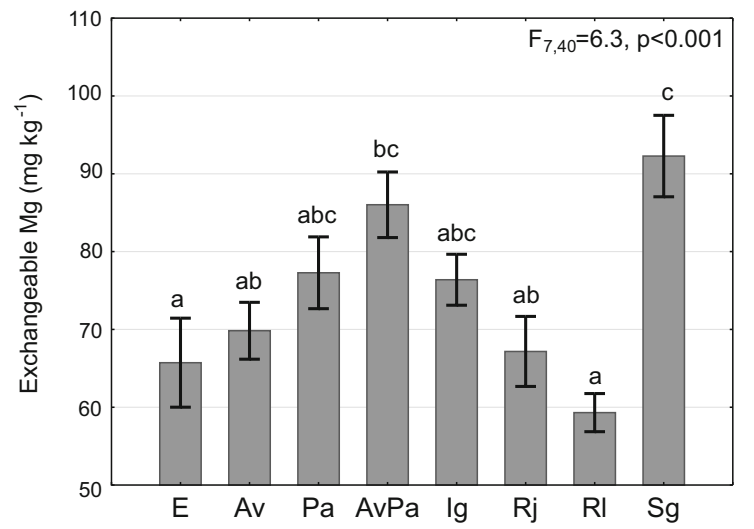

(b)

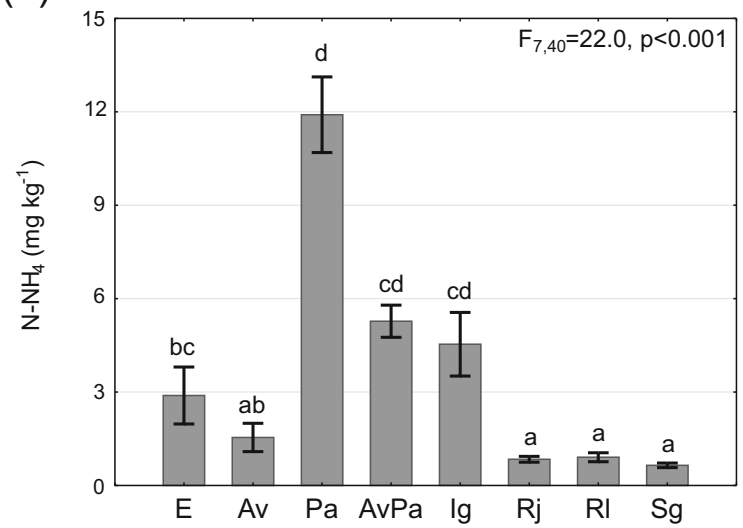

(d)

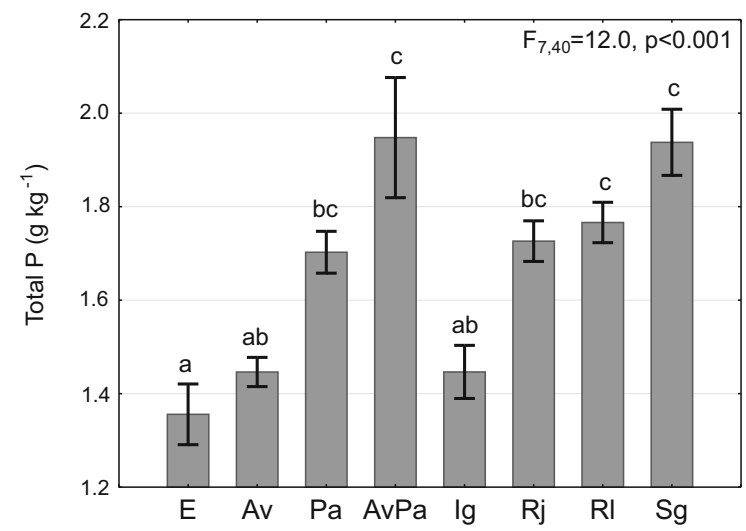

(f)

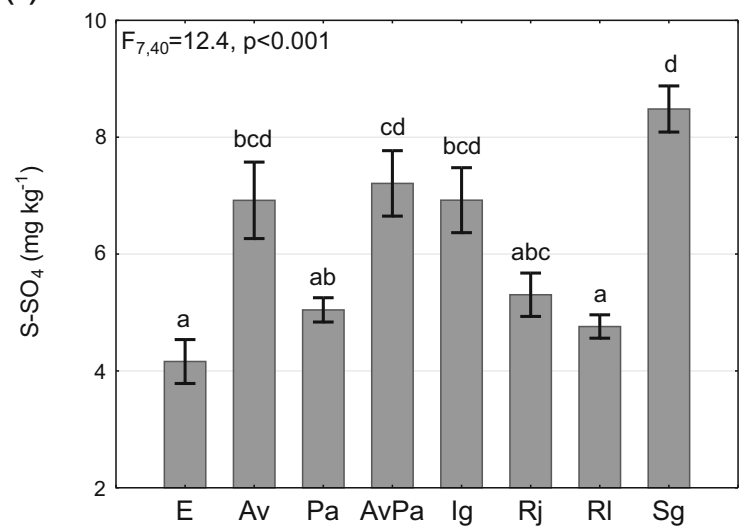

(h)

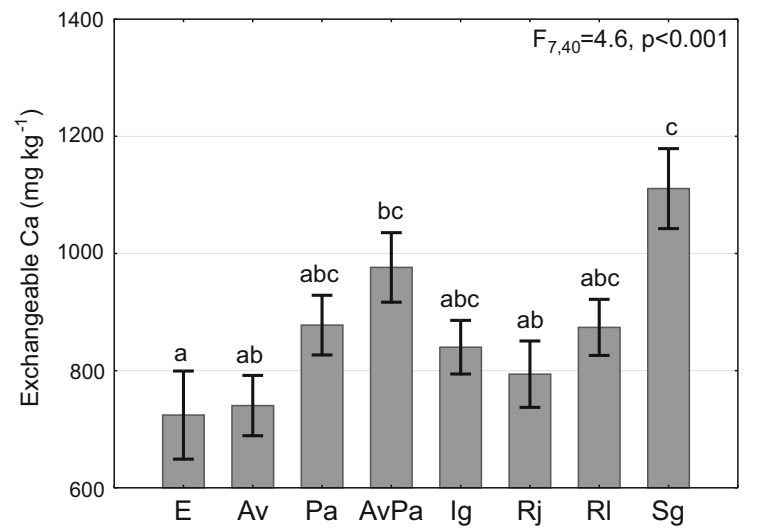


the modification of denitrification and $\mathrm{N}$ mineralization processes via secondary metabolites (Hirose and Tateno 1984; Tharayil et al. 2013; Bardon et al. 2016; Stefanowicz et al. 2017). However, the effect of $R$. japonica on $\mathrm{N}-\mathrm{NO}_{3}$ concentration was not evident in our experiment. The concentration of $\mathrm{N}^{-\mathrm{NO}_{3}}$ in valley soil was actually higher under $R$. japonica than under some native and invasive species, but no such differences were found in the case of fallow soil.

The variability in the soil response to plant invasion revealed by different studies may be caused by a number of reasons, among which the most important are functional traits of invasive species and native vegetation, properties of recipient soil, season, and length of invasion history (Dassonville et al. 2008; Liao et al. 2008; Scharfy et al. 2011; Tharayil et al. 2013). Plants affect the soil environment through deposition of litter, exudation of chemical compounds via roots, or their leaching from plants by rain, as well as through nutrient uptake (Hobbie 1992; Orwin et al. 2010; Haichar et al. 2014; Ruckli et al. 2014a). It is known that invasive plant species often produce huge amounts of biomass which differs considerably from that of native vegetation in chemical quality, for example lignin and element content, $\mathrm{C} / \mathrm{N}$ and lignin $/ \mathrm{N}$ ratios, and/or secondary metabolite concentrations (Dassonville et al. 2007, 2008; Tharayil et al. 2013; Mincheva et al. 2014). Large quantities of senescent plant biomass reach the soil surface during litterfall and undecomposed litter fragments may accumulate in the form of a thick layer if the litter quality, and hence, its decomposition rate are low. Such a phenomenon was observed in R. japonica, contributing to changes in both soil properties and plant communities (Maurel et al. 2010; Stefanowicz et al. 2016; Stefanowicz et al. 2017). The quality and quantity of plant biomass differ considerably among invasive species. Dassonville et al. (2008) found that the amount of biomass of $R$. japonica was much higher than that of I. glandulifera and S. gigantea, and the tissues of I. glandulifera contained more nutrients that the two other species.

It should be noted, however, that litter deposition by plants growing in a pot experiment hardly mimics that by wellestablished stands of vegetation in natural conditions. Litterfall was considerably restricted in this experiment due to its short duration and low plant biomass. Only R. japonica, the biomass of which was an order of magnitude higher than the biomass of other species, deposited noticeable amount of leaf litter in one season and could have a measurable effect on soil properties through leaching of elements or phenolics from that litter (Berg and McClaugherty 2008; Tharayil et al. 2013). Therefore, it may be supposed that the strong and multidirectional soil response to the presence of invasive species in our experiment was mainly triggered by nutrient uptake and exudation of species-specific chemical compounds via plant roots, though plant growth was suggested to exert a weaker effect on soil than plant detrital inputs (Dornbush 2007). Plant
Fig. 5 Physicochemical properties of valley soil (means and standard errors). Only variables highly contributing to the discrimination of plant species treatments are presented. Means bearing different letters differ significantly $(p<0.05)$ according to Tukey's HSD test. Plant species: E-empty pot (bare soil); Native: Av-A. vulgaris, $\mathrm{Pa}-$ $P$. arundinacea, $\mathrm{AvPa}-\mathrm{a}$ mixture of $A$. vulgaris and $P$. arundinacea; Invasive: $\mathrm{Ig}-I$. glandulifera, $\mathrm{Rj}-R$. japonica, $\mathrm{Rl}-R$. laciniata, $\mathrm{Sg}-$ S. gigantea

roots exude a number of compounds, among others, sugars, organic acids, amino acids, proteins, enzymes, phenolics, and inorganic ions, which act as nutrient source, chemoattractant signals, chelators of mineral nutrients, plant defenders or modifiers of plant, and microbial growth (Haichar et al. 2014). Rhizodeposition is influenced by many biotic and abiotic factors such as plant species, developmental status, evapotranspiration, root age, rooting depth, mycorrhiza, soil type, nutrient deficiency, temperature, moisture, and many more (Jones et al. 2004). Root exudation of secondary metabolites may play a particularly important role in the case of invasive plant as these compounds potentially contribute to the invasion success of some species - a phenomenon called novel weapons hypothesis (Callaway and Ridenour 2004). They can act not only as allelopathic agents but also as mediators in plant-soil microbial interactions, thereby potentially altering the rate of soil processes and nutrient concentrations in soil (Callaway and Ridenour 2004).

In our experiment, plant roots were very long and present in the whole volume of soil under all species except I. glandulifera. In the case of the latter species, the roots were much shorter and grew only in the surface soil. In fact, the rooting depth of $I$. glandulifera is shallower $(10-15 \mathrm{~cm})$ in comparison to some other invaders, for example $R$. japonica (2 m) (Beerling and Perrins 1993; Weston et al. 2005). The differences in the rooting depth between I. glandulifera and other species observed in experimental pots may have contributed to some extent to differential influence of this species on soil. Low belowground and aboveground biomass of I. glandulifera may have resulted in a weak influence of this species on soil, and thus, in a relative similarity of its soil to both native and bare soils.

While the tissues or litter of I. glandulifera, R. japonica, $R$. laciniata, and $S$. gigantea have been assessed in respect of element and/or secondary metabolite concentrations and some authors tried to link their tissue quality with the soil environment (Kalemba et al. 2001; Dassonville et al. 2008; Fan et al. 2009; Aguilera et al. 2010; Tharayil et al. 2013; Bardon et al. 2014; Ruckli et al. 2014a; Stefanowicz et al. 2017), much less is known on the quality of root exudates of these species or their effects on physicochemical and biological soil properties (Scharfy et al. 2010; Ruckli et al. 2014a). Ruckli et al. (2014a) found that I. glandulifera is able to inhibit mycelium growth by naphthoquinones - phenolics released from roots or leached from leaves by rain. On the other hand, 3-year growth 
(a)

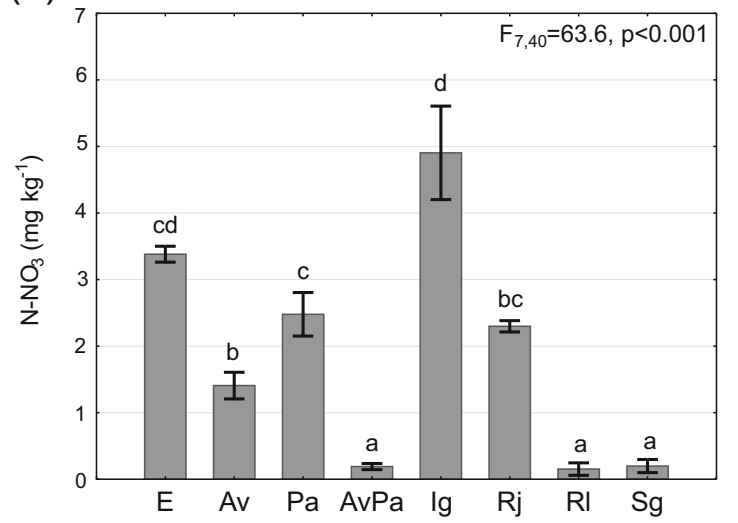

(c)

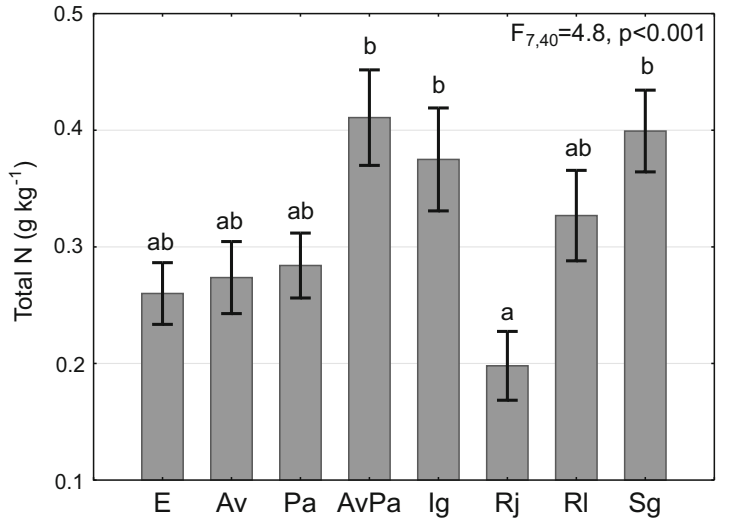

(e)

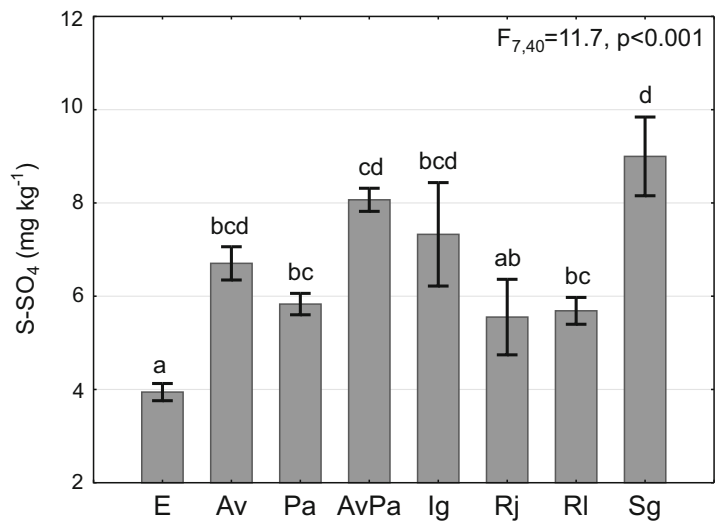

(g)

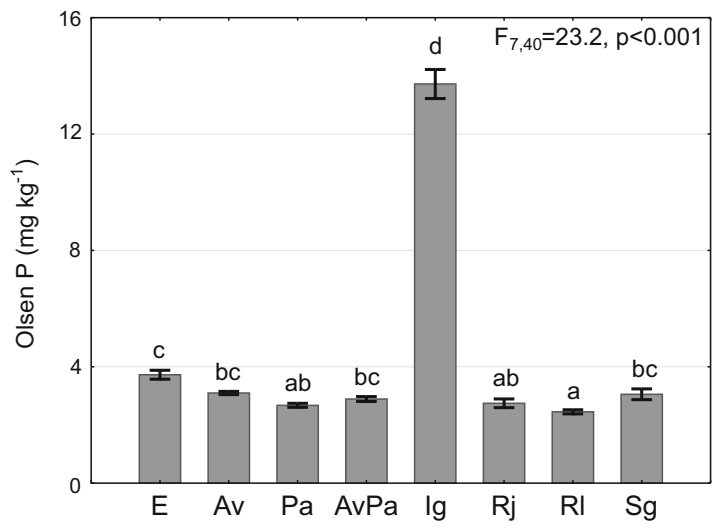

(b)

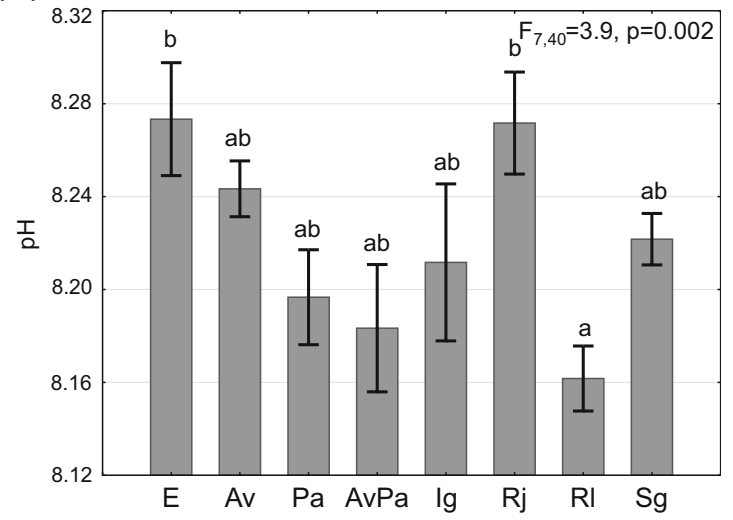

(d)

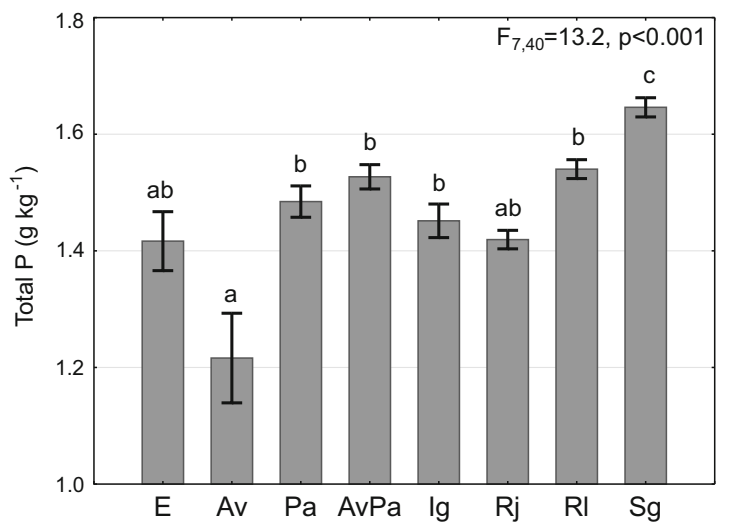

(f)

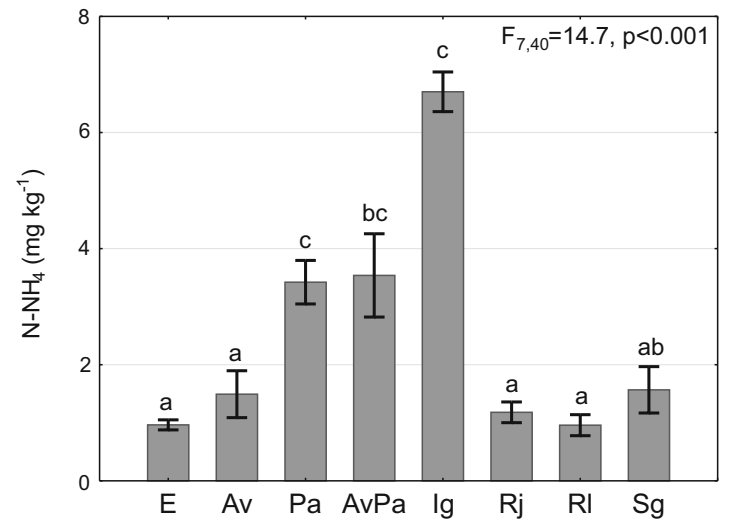

(h)

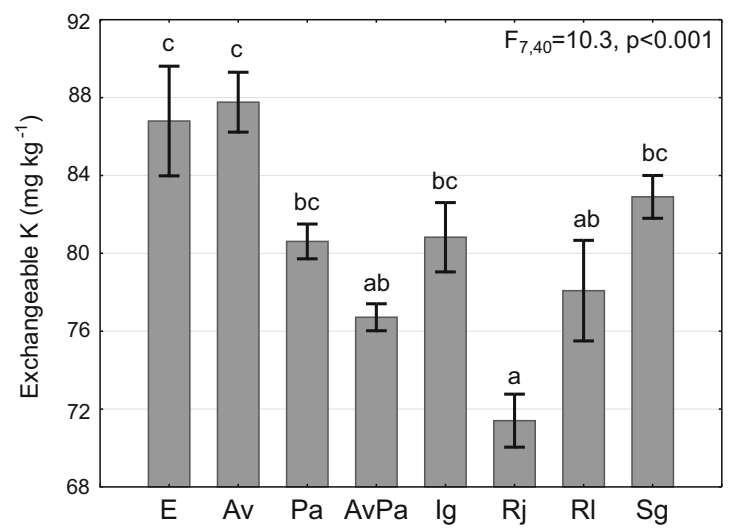




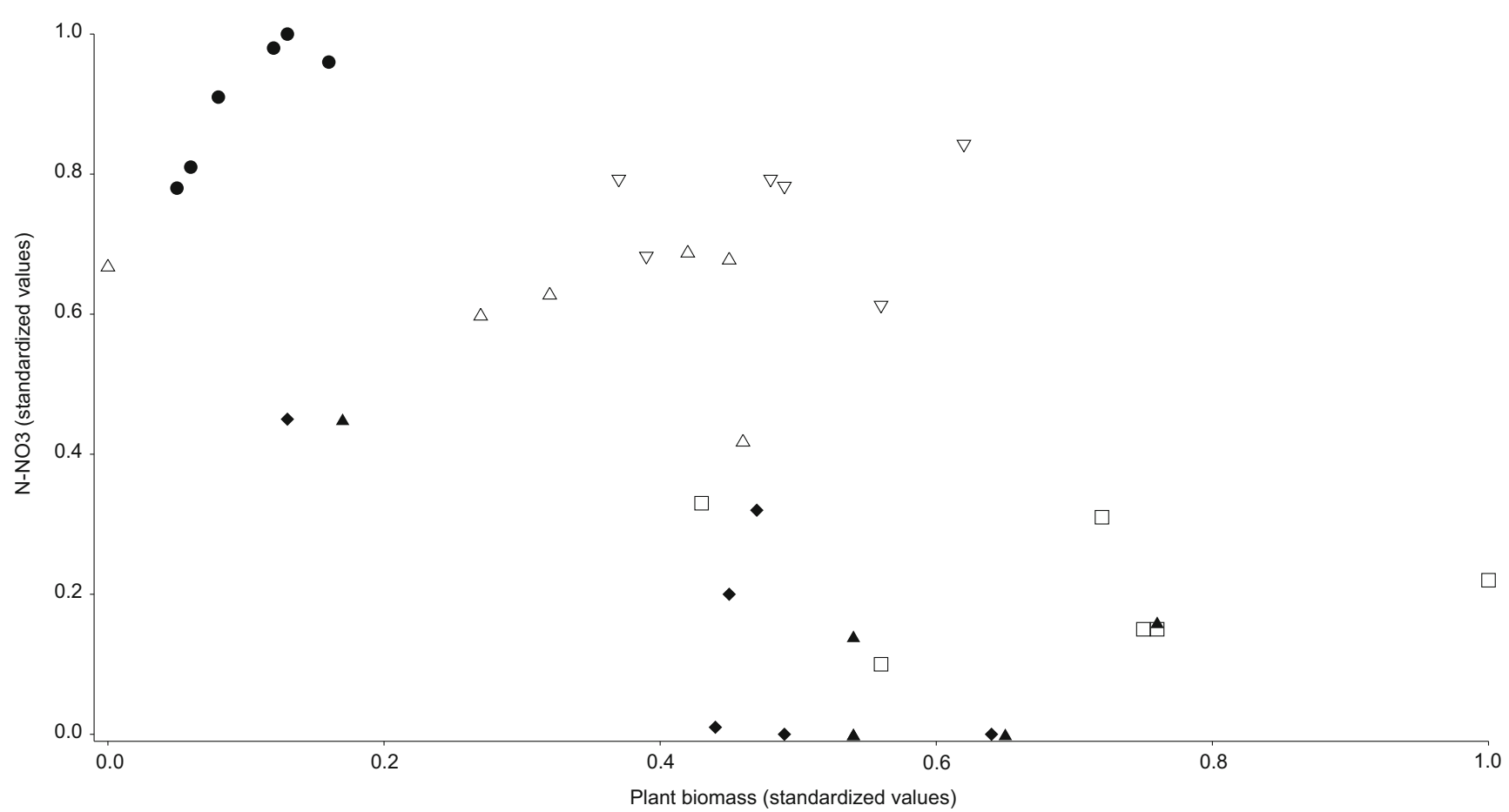

Fig. 6 Relationship between plant biomass and $\mathrm{N}_{-} \mathrm{NO}_{3}$ concentration in valley soil. Black symbols indicate invasive species (black dotsI. glandulifera, black triangles-R. laciniata, black diamonds-

of $S$. gigantea in experimental wetland plant communities influenced neither $\mathrm{N}$ nor $\mathrm{P}$ availability in soil (Scharfy et al. 2010).

There are some data indicating that invasive plant species differ from native ones in terms of nutrient uptake. Solidago gigantea took up about twice as much P per unit area as native plants, possibly due to its higher productivity, deeper rooting system, or more effective exploitation of mycorrhizal symbiosis (Chapuis-Lardy et al. 2006). Actually, Majewska et al. (2017) reported that the growth of S. gigantea and R. laciniata and $\mathrm{P}$ content in their tissues were enhanced by arbuscular mycorrhizal fungi. Dassonville et al. (2007) stressed the importance of high productivity and nutrient uplift from deep soil horizons as mechanisms driving changes in topsoil chemical composition induced by the invasion of $R$. japonica. However, the latter mechanism does not play a role in relatively shallow experimental pots.

The differences between the two native species in their effects on soil were rather minor when compared to those among invasive species. Soils under A. vulgaris and $P$. arundinacea differed in $\mathrm{N}-\mathrm{HN}_{4}, \mathrm{~N}-\mathrm{NO}_{3}$, and/or total $\mathrm{P}$, which mostly were higher under the latter species. These natives were expected to affect soil differently as they belong to distinct functional groups - forbs and graminoids, which differ from each other in many traits, for example, tissue density, leaf thickness, leaf life span, and litter decomposability (Scharfy et al. 2011). It should be kept in mind that A. vulgaris and $P$. arundinacea are native expansive species
S. gigantea), empty symbols indicate native species (trianglesA. vulgaris, inverted triangles $-P$. arundinacea and squares - a mixture of $A$. vulgaris and $P$. arundinacea). Pearson's $r=-0.64, p<0.001$

in Europe, but noxious invaders in some other parts of the world, for example, North America (Weston et al. 2005; Jacinthe et al. 2010). In this context, data on their effects on soil gathered in this study seem particularly valuable.

In our experiment, the effects of plant invasion varied among the two soils, probably because the soils differed in nearly all physicochemical properties, i.e., total and/or available concentrations of most elements, organic matter content, WHC, and $\mathrm{pH}$. Other studies also suggested that the effects of invasion may depend on the properties of recipient soil (Dassonville et al. 2008; Scharfy et al. 2009). Dassonville et al. (2008) observed a positive impact of plant invasion on nutrient concentrations in soils with initially low nutrient levels and a negative impact under the opposite conditions. In turn, Scharfy et al. (2009) found that the effects of invasion on some soil physicochemical properties depended on P availability, being more evident at P-rich sites. In our experiment, plantsoil feedback was observed as more fertile (in terms of organic matter and $\mathrm{N}$ content) fallow soil generally maintained plants characterized by higher biomass than plants on poorer valley soil. The differences in plant biomass between the soil types may have contributed further to differences in invasion effects on these soils. As mentioned earlier, only restricted response of soil physicochemical characteristics to the invasion of $R$. japonica, $R$. laciniata, and S. gigantea was observed in our previous field research, which used many study sites in order to search for general patterns of invasion effects on soil (Stefanowicz et al. 2017). An explanation for the weak overall 
soil response could be that the soils actually changed due to the invasion but the direction of the changes varied among soils. Therefore, no significant invasion influence could be found when analyzing the data across all sites. This experiment seems to support the explanation as invasive species growing in pots did induce considerable alterations in soil, but the changes usually differed between soils in magnitude and direction.

\section{Conclusions}

Although short-term pot experiments based on plant cultivation do not ideally mimic the field situation due to their short duration, lower plant biomass and litter deposition, and/or restricted rooting depth, they can be considered a valuable complement of space-for-time substitution field studies, simulating a primary stage of the encroachment of alien plants onto disturbed bare soil. Our experiment showed that the growth of invasive plants significantly influenced most soil physicochemical properties. The influence differed both between invasive and native species as well as among invasive species. The multidirectional effects of different invaders resulted in a considerable divergence in soil characteristics, mainly in total and available forms of $\mathrm{N}$ and $\mathrm{P}, \mathrm{S}_{-} \mathrm{SO}_{4}$, exchangeable $\mathrm{K}$, and $\mathrm{Mg}$, as well as $\mathrm{pH}$. As biomass produced by plants growing in pots was generally low and litter deposition negligible, it may be supposed that the plants influenced soil through the exudation of chemical compounds via roots and nutrient uptake. Such invasion-driven changes in the soil environment may trigger feedbacks that stabilize or accelerate invasion and hinder re-colonization by native vegetation, which has implications for the restoration of invaded habitats.

Acknowledgements The authors thank Angelika Banaś and Elżbieta Chrzanowska for their help with the laboratory work.

Funding The research was funded by the National Science Centre, Poland, under the project DEC-2011/03/B/NZ8/00008 (2012-16). It also received financial support from the Institute of Botany at the Jagiellonian University (K/ZDS/005399, K/ZDS/006305) and the W. Szafer Institute of Botany, Polish Academy of Sciences.

Open Access This article is distributed under the terms of the Creative Commons Attribution 4.0 International License (http:// creativecommons.org/licenses/by/4.0/), which permits unrestricted use, distribution, and reproduction in any medium, provided you give appropriate credit to the original author(s) and the source, provide a link to the Creative Commons license, and indicate if changes were made.

\section{References}

Aguilera AG, Alpert P, Dukes JS, Harrington R (2010) Impacts of the invasive plant Fallopia japonica (Houtt.) on plant communities and ecosystem processes. Biol Invasions 12(5):1243-1252. https://doi. org/10.1007/s10530-009-9543-Z
Akasaka M, Osawa T, Ikegami M (2015) The role of roads and urban area in occurrence of an ornamental invasive weed: a case of Rudbeckia laciniata L. Urban Ecosyst 18(3):1021-1030. https://doi.org/10. 1007/s11252-015-0466-4

Bardon C, Piola F, Bellvert F, Haichar FZ, Comte G, Meiffren G, Pommier T, Puijalon S, Tsafack N, Poly F (2014) Evidence for biological denitrification inhibition (BDI) by plant secondary metabolites. New Phytol 204(3):620-630. https://doi.org/10.1111/nph. 12944

Bardon C, Piola F, Haichar FZ, Meiffren G, Comte G, Missery B, Balby M, Poly F (2016) Identification of B-type procyanidins in Fallopia spp. involved in biological denitrification inhibition. Environ Microbiol 18(2):644-655. https://doi.org/10.1111/1462-2920. 13062

Barney JN (2006) North American history of two invasive plant species: phytogeographic distribution, dispersal vectors, and multiple introductions. Biol Invasions 8(4):703-717. https://doi.org/10.1007/ s10530-005-3174-9

Barney JN, Tharayil N, DiTommaso A, Bhowmik PC (2006) The biology of invasive alien plants in Canada. 5. Polygonum cuspidatum Sieb. \& Zucc. [=Fallopia japonica (Houtt.) Ronse Decr.] Can J Plant Sci 86(3):887-906. https://doi.org/10.4141/P05-170

Beerling DJ, Perrins JM (1993) Impatiens glandulifera Royle (Impatiens roylei Walp.) J Ecol 81(2):367-382. https://doi.org/10.2307/ 2261507

Berg B, McClaugherty C (2008) Plant litter. Decomposition, humus formation, carbon sequestration. Springer-Verlag, Berlin Heidelberg

Broadbent AAD, Orwin KH, Peltzer DA, Dickie IA, Mason NWH, Ostle NJ, Stevens CJ (2017) Invasive N-fixer impacts on litter decomposition driven by changes to soil properties not litter quality. Ecosystems 20(6):1151-1163. https://doi.org/10.1007/s10021-0160099-3

CABI (2017) Invasive species compendium. https://www.cabi.org/isc/ datasheet/48032. Accessed 6 November 2017

Callaway RM, Ridenour WM (2004) Novel weapons: invasive success and the evolution of increased competitive ability. Front Ecol Environ 2(8):436-443. https://doi.org/10.1890/1540-9295(2004) 002[0436:NWISAT]2.0.CO;2

Castro-Díez P, Alonso Á (2017) Alteration of nitrogen cycling as a result of invasion. In: Vilà M, Hulme PE (eds) Impact of biological invasions on ecosystem services. Springer International Publishing, Switzerland, pp 49-62. https://doi.org/10.1007/978-3-319-45121-3 4

Castro-Díez P, Godoy O, Alonso A, Gallardo A, Saldaña A (2014) What explains variation in the impacts of exotic plant invasions on the nitrogen cycle? A meta-analysis. Ecol Lett 17(1):1-12. https://doi. org/10.1111/ele.12197

Chapuis-Lardy L, Vanderhoeven S, Dassonville N, Koutika L-S, Meerts P (2006) Effect of the exotic invasive plant Solidago gigantea on soil phosphorus status. Biol Fertil Soils 42(6):481-489. https://doi. org/10.1007/s00374-005-0039-4

Corbin JD, D'Antonio CM (2012) Gone but not forgotten? Invasive plants' legacies on community and ecosystem properties. Invasive Plant Sci Manag 5(01):117-124. https://doi.org/10.1614/IPSM-D11-00005.1

Čuda J, Vítková M, Albrechtová M, Guo W-Y, Barney JN, Pyšek P (2017) Invasive herb Impatiens glandulifera has minimal impact on multiple components of temperate forest ecosystem function. Biol Invasions 19(10):3051-3066. https://doi.org/10.1007/s10530017-1508-Z

Dassonville N, Vanderhoeven S, Gruber W, Meerts P (2007) Invasion by Fallopia japonica increases topsoil mineral nutrient concentrations. Ecoscience 14(2):230-240. https://doi.org/10.2980/11956860(2007)14[230:IBFJIT]2.0.CO;2

Dassonville N, Vanderhoeven S, Vanparys V, Hayez M, Gruber W, Meerts P (2008) Impacts of alien invasive plants on soil nutrients 
are correlated with initial site conditions in NW Europe. Oecologia 157(1):131-140. https://doi.org/10.1007/s00442-008-1054-6

Dornbush ME (2007) Grasses, litter, and their interaction affect microbial biomass and soil enzyme activity. Soil Biol Biochem 39(9):22412249. https://doi.org/10.1016/j.soilbio.2007.03.018

Fan P, Hay A-E, Marston A, Lou H, Hostettmann K (2009) Chemical variability of the invasive neophytes Polygonum cuspidatum Sieb. and Zucc. and Polygonum sachalinensis F. Schmidt ex Maxim. Biochem Syst Ecol 37(1):24-34. https://doi.org/10.1016/j.bse. 2008.11.018

Güsewell S, Zuberbühler N, Clerc C (2005) Distribution and functional traits of Solidago gigantea in a Swiss lakeshore wetland. Bot Helv 115(1):63-75. https://doi.org/10.1007/s00035-005-0721-Z

Haichar FZ, Santaella C, Heulin T, Achouak W (2014) Root exudates mediated interactions belowground. Soil Biol Biochem 77:69-80. https://doi.org/10.1016/j.soilbio.2014.06.017

Hammer Ø, Harper DAT, Ryan PD (2001) PAST: paleontological statistics software package for education and data analysis. Palaeontol Electron 4:1-9

Hejda M, Pyšek P (2006) What is the impact of Impatiens glandulifera on species diversity of invaded riparian vegetation? Biol Conserv 132(2):143-152. https://doi.org/10.1016/j.biocon.2006.03.025

Hejda M, Pyšek P, Jarošík V (2009) Impact of invasive plants on the species richness, diversity and composition of invaded communities. J Ecol 97(3):393-403. https://doi.org/10.1111/j.1365-2745.2009. $01480 . x$

Hirose T, Tateno M (1984) Soil nitrogen patterns induced by colonization of Polygonum cuspidatum on Mt. Fuji. Oecologia 61(2):218-223. https://doi.org/10.1007/BF00396764

Hobbie SE (1992) Effects of plant species on nutrient cycling. Trees 7: 336-339

ISO 11260 (1996) Soil quality - determination of effective cation exchange capacity and base saturation level using barium chloride solution. ISO, Geneve

ISO 11277 (1998) Soil quality — determination of particle size distribution in mineral soil material — method by sieving and sedimentation. ISO, Geneve

Jacinthe P-A, Bills JS, Tedesco LP (2010) Size, activity and catabolic diversity of the soil microbial biomass in a wetland complex invaded by reed canary grass. Plant Soil 329(1-2):227-238. https://doi.org/ 10.1007/s11104-009-0147-2

Jones DL, Hodge A, Kuzyakov Y (2004) Plant and mycorrhizal regulation of rhizodeposition. New Phytol 163(3):459-480. https://doi. org/10.1111/j.1469-8137.2004.01130.x

Kalemba D, Marschall H, Bradesi P (2001) Constituents of the essential oil of Solidago gigantea Ait. (giant goldenrod). Flavour Fragr J 16(1):19-26. https://doi.org/10.1002/1099-1026(200101/02)16: $1<19::$ AID-FFJ940>3.0.CO;2-U

Lavoie C (2017) The impact of invasive knotweed species (Reynoutria spp.) on the environment: review and research perspective. Biol Invasions 19(8):2319-2337. https://doi.org/10.1007/s10530-0171444-y

Lenda M, Witek M, Skórka P, Moroń D, Woyciechowski M (2013) Invasive alien plants affect grassland ant communities, colony size and foraging behaviour. Biol Invasions 15(11):2403-2414. https:// doi.org/10.1007/s10530-013-0461-8

Liao C, Peng R, Luo Y, Zhou X, Wu X, Fang C, Chen J, Li B (2008) Altered ecosystem carbon and nitrogen cycles by plant invasion: a meta-analysis. New Phytol 177(3):706-714. https://doi.org/10. $1111 / j .1469-8137.2007 .02290 . x$

Majewska ML, Błaszkowski J, Nobis M, Rola K, Nobis A, Łakomiec D, Czachura P, Zubek S (2015) Root-inhabiting fungi in alien plant species in relation to invasion status and soil chemical properties. Symbiosis 65(3):101-115. https://doi.org/10.1007/s13199-0150324-4
Majewska ML, Rola K, Zubek S (2017) The growth and phosphorus acquisition of invasive plants Rudbeckia laciniata and Solidago gigantea are enhanced by arbuscular mycorrhizal fungi. Mycorrhiza 27(2):83-94. https://doi.org/10.1007/s00572-0160729-9

Maurel N, Salmon S, Ponge JF, Machon N, Moret J, Muratet A (2010) Does the invasive species Reynoutria japonica have an impact on soil and flora in urban wastelands? Biol Invasions 12(6):1709-1719. https://doi.org/10.1007/s10530-009-9583-4

Miejskie Przedsiębiorstwo Wodociagów i Kanalizacji S.A. w Krakowie (2015) Raport roczny. http://wodociagi.krakow.pl/admin/files/Files/ Raporty_roczne/Raport_2015.pdf. Accessed 6 November 2017

Miejskie Przedsiębiorstwo Wodociagów i Kanalizacji S.A. w Krakowie (2016) Raport roczny. http://wodociagi.krakow.pl/admin/files/Files/ Raporty_roczne/Raport_2016_PRV.pdf. Accessed 6 November 2017

Mincheva T, Barni E, Varese GC, Brusa G, Cerabolini B, Siniscalco C (2014) Litter quality, decomposition rates and saprotrophic mycoflora in Fallopia japonica (Houtt.) Ronse Decraene and in adjacent native grassland vegetation. Acta Oecol 54:29-35. https://doi.org/ 10.1016/j.actao.2013.03.010

Öhlinger R (1996) Maximum water-holding capacity. In: Schinner F, Öhlinger R, Kandeler E, Margesin R (eds) Methods in soil biology. Springer-Verlag, Berlin Heidelberg, pp 385-386. https://doi.org/10. 1007/978-3-642-60966-4_28

Orwin KH, Buckland SM, Johnson D, Turner BL, Smart S, Oakley S, Bardgett RD (2010) Linkages of plant traits to soil properties and the functioning of temperate grassland. J Ecol 98(5):1074-1083. https:// doi.org/10.1111/j.1365-2745.2010.01679.x

Pyšek P, Prach K (1995) Invasion dynamics of Impatiens glandulifera - a century of spreading reconstructed. Biol Conserv 74(1):41-48. https://doi.org/10.1016/0006-3207(95)00013-T

Quist CW, Vervoort MTW, Van Megen H, Gort G, Bakker J, Van der Putten WH, Helder J (2014) Selective alteration of soil food web components by invasive giant goldenrod Solidago gigantea in two distinct habitat types. Oikos 123(7):837-845. https://doi.org/10. 1111/oik.01067

Richardson DM, Pyšek P, Rejmánek M, Barbour DM, Panetta FD, West CJ (2000) Naturalization and invasion of alien plants: concepts and definitions. Divers Distrib 6(2):93-107. https://doi.org/10.1046/j. 1472-4642.2000.00083.x

Rodríguez-Caballero G, Caravaca F, Alguacil MM, Fernández-López M, Fernández-González AJ, Roldán A (2017) Striking alterations in the soil bacterial community structure and functioning of the biological $\mathrm{N}$ cycle induced by Pennisetum setaceum invasion in a semiarid environment. Soil Biol Biochem 109:176-187. https://doi.org/10. 1016/j.soilbio.2017.02.012

Ruckli R, Hesse K, Glauser G, Rusterholz HP, Baur B (2014a) Inhibitory potential of naphthoquinones leached from leaves and exuded from roots of the invasive plant Impatiens glandulifera. J Chem Ecol 40(4):371-378. https://doi.org/10.1007/s10886-014-0421-5

Ruckli R, Rusterholz HP, Baur B (2013) Invasion of Impatiens glandulifera affects terrestrial gastropods by altering microclimate. Acta Oecol 47:16-23. https://doi.org/10.1016/j.actao.2012.10.011

Ruckli R, Rusterholz HP, Baur B (2014b) Invasion of an annual exotic plant into deciduous forests suppresses arbuscular mycorrhiza symbiosis and reduces performance of sycamore maple saplings. For Ecol Manag 318:285-293. https://doi.org/10.1016/j.foreco.2014. 01.015

Scharfy D, Eggenschwiler H, Olde Venterink H, Edwards PJ, Güsewell S (2009) The invasive alien plant species Solidago gigantea alters ecosystem properties across habitats with differing fertility. J Veg Sci 20(6):1072-1085. https://doi.org/10.1111/j.1654-1103.2009. 01105.x

Scharfy D, Funk A, Olde Venterink H, Güsewell S (2011) Invasive forbs differ functionally from native graminoids, but are similar to native 
forbs. New Phytol 189(3):818-828. https://doi.org/10.1111/j.14698137.2010.03531.x

Scharfy D, Güsewell S, Gessner MO, Olde Venterink H (2010) Invasion of Solidago gigantea in contrasting experimental plant communities: effects on soil microbes, nutrients and plant-soil feedbacks. J Ecol 98(6):1379-1388. https://doi.org/10.1111/j.1365-2745.2010. 01722.x

Stefanowicz AM, Stanek M, Nobis M, Zubek S (2016) Species-specific effects of plant invasions on activity, biomass, and composition of soil microbial communities. Biol Fertil Soils 52(6):841-852. https:// doi.org/10.1007/s00374-016-1122-8

Stefanowicz AM, Stanek M, Nobis M, Zubek S (2017) Few effects of invasive plants Reynoutria japonica, Rudbeckia laciniata and Solidago gigantea on soil physical and chemical properties. Sci Total Environ 574:938-946. https://doi.org/10.1016/j.scitotenv. 2016.09.120

Tharayil N, Alpert P, Bhowmik P, Gerard P (2013) Phenolic inputs by invasive species could impart seasonal variations in nitrogen pools in the introduced soils: a case study with Polygonum cuspidatum. Soil Biol Biochem 57:858-867. https://doi.org/10.1016/j.soilbio. 2012.09.016

Tokarska-Guzik B, Węgrzynek B, Urbisz A, Urbisz A, Nowak T, Bzdęga K (2010) Alien vascular plants in the Silesian Upland of Poland: distribution, patterns, impacts and threats. Biodiv Res Conserv 19: $33-54$

Van Kleunen M, Weber E, Fischer M (2010) A meta-analysis of trait differences between invasive and non-invasive plant species. Ecol Lett 13(2):235-245. https://doi.org/10.1111/j.1461-0248.2009. 01418.x
Vanderhoeven S, Dassonville N, Chapuis-Lardy L, Hayez M, Meerts P (2006) Impact of the invasive alien plant Solidago gigantea on primary productivity, plant nutrient content and soil mineral nutrient concentrations. Plant Soil 286(1-2):259-268. https://doi.org/10. 1007/s11104-006-9042-2

Vanderhoeven S, Dassonville N, Meerts P (2005) Increased topsoil mineral nutrient concentrations under exotic invasive plants in Belgium. Plant Soil 275(1-2):169-179. https://doi.org/10.1007/s11104-005-1257-0

Weber E (1998) The dynamics of plant invasions: a case study of three exotic goldenrod species (Solidago L.) in Europe. J Biogeogr 25(1): 147-154. https://doi.org/10.1046/j.1365-2699.1998.251119.x

Weston LA, Barney JN, DiTommaso A (2005) A review of the biology and ecology of three invasive perennials in New York State: Japanese knotweed (Polygonum cuspidatum), mugwort (Artemisia vulgaris) and pale swallow-wort (Vincetoxicum rossicum). Plant Soil 277(1-2):53-69. https://doi.org/10.1007/s11104-005-3102-x

Vilà M, Espinar JL, Hejda M, Hulme PE, Jarošik V, Maron JL, Pergl J, Schaffner U, Sun Y, Pyšek P (2011) Ecological impacts of invasive alien plants: a meta-analysis of their effects on species, communities and ecosystems. Ecol Lett 14(7):702-708. https://doi.org/10.1111/j. 1461-0248.2011.01628.x

Zelnik I (2012) The presence of invasive alien plant species in different habitats: case study from Slovenia. Acta Biol Slov 55:25-38

Zubek S, Majewska ML, Błaszkowski J, Stefanowicz AM, Nobis M, Kapusta P (2016) Invasive plants affect arbuscular mycorrhizal fungi abundance and species richness as well as the performance of native plants grown in invaded soils. Biol Fertil Soils 52(6):879893. https://doi.org/10.1007/s00374-016-1127-3 